\title{
CHROMOSOME NUMBERS IN SOME MEXICAN GRASSES ${ }^{1}$
}

\author{
by \\ Frank W. Gould ${ }^{2}$
}

INTRODUCTION - The basic pattern of chromosome numbers in the grass family was first outlined by Avdulov in 1931. In the relatively short time since the appearance of this highly significant treatment, many chromosome records and other cytological data pertaining to grasses have been published and the general aspects of cytology as applied to grass taxonomy are now well known.

Existing grass chromosome records, however, are inadequate to contributs. significantly to systematic studies of many genera and species complexes. Chromosome numbers and associated cytological data for many grass species are based on single collections. Some records have been reported without reference to definite collection locality or herbarium voucher specimen and are of little or no value in the correlation of cytological characteristics with other plant characters. Series of well-documented cytological records, based on plants throughout the range of the taxa involved, are highly desirable in the determination of phylogenetic relittionships and patterns of plant dispersal.

The relatively high incidence of polyploidy in the Gramineae is well known. Stebbins (1950) has estimated that about two-thirds of all grass species are polyploid. Two or more levels of ploidy are present in most large genera. Also, hybridization followed by doubling of chromosome number and the return of fertility is an especially important evolutionary phenomenon in the Gramineae. Differences in chromosome number not only exist between closely related species but also occur within populations of the same species. Such variation may or may not be associated with intercrossing, and also may or may not affect sexual reproduction.

Although Mexico is noted for its diverse grass flora and its extensive areas of natural grasslands, chromosome records based on Mexican grasses are relatively few. Beaman et al. (1962), in an article reporting studies af alpine and subalpine plants, listed chromosome counts for 6 genera and 11 species of Mexican grasses. In the same year (1962), Tateoka reported counts for 27 genera and 38 species of Mexican grasses. The writer has reported counts, based on Mexican collections, for 14 genera and 26 species (Gould, 1953, 1956, 1958, 1963; Gould, and Kapadia, 1964).

I Technical Articles No. 4768. Texas Agricultural Experiment Station, College Station, Texas. Research supported by grants G-6372 and G-19428 from the National Science Foundation. The writer is indebted to Mr. Jason R. Swallen and Dr. T. S. Soderstrom for assistance in specimen identification.

2 Professor, Department of Range and Forestry, Texas A. \& M. University. 
In the present article, chromosome numbers are given for 120 collections, representing 30 genera and 64 species. The counts for 41 species are the first for the taxon or are different from those previously reported. The chromosome records for species of Aegopogon, Cathestecum, Microchloa, and Ixophorus are the first for these genera.

The grouping of genera into subfamilies and tribes follows the system presented by Stebbins and Crampton (1961) and is essentinally the same as that used by the writer in two papers reporting chromosome numbers for grasses of southwestern U. S. A. $(1958,1960)$.

MATERIALES AND METHODS - All chromosome studies were made from meiotic division of pollen mother cells (PMC). Sporocyte material was taken from plants growing in their natural sites and also from greenhouse and garden plants grown from seed. The material was killed and fixed in the standard 3:1 absolute alcohol-glacial acetic acid for 24 hours and then transferred to 70 per cent alcohol for storage in the refrigerator. Satisfactory chromosome preparations were made by using the regular aceto-carmine technique even after more than 12 months storage. Voucher specimens for the chromosome records are on file in the Tracy Herbarium of Texas A \& M University. A duplicate series of most of the collection; also has been deposited in the herbarium of the University of California.

RESULTS AND DISCUSSION - The chromosome counts for Mexican grasses recorded in the present study are listed in Table 1.

Subfamily FESTUCOIDEAE.-Tribe Avenae. Chromosome counts of $2 \mathrm{n}=28$ were obtained for Trisetum deyeuxoides (fig. 1) and $T$. evolutum. The count for the former is the same as obtained by Tateoka (1962), and the count for the latter was the first for this taxon.

Tribe Stipeae. The count of $2 \mathrm{n}=22$ was the first recorded for Piptochaetium brevicalyx (fig. 2), A plant of P. fimbriatum from near San Luis Potosí was determined to have $2 \mathrm{n}=42$ chromosomes (fig. 3). Brown (1951 apparently obtained $2 \mathrm{n}-44$, for P. fimbriatum; his chart and camera lucida drawing show this number but in the text the count is listed as $2 n=22$.

A record of $2 \mathrm{n}=44$ was obtained for Stipa eminens. Although this number ap. pears to be euploid on the basis of $\mathrm{x}=11$, the two previous counts for the taxon were $2 \mathrm{n}=4.6$ (Love, 1947; Brown, 1951).

Subfamily ERAGROSTOIDEAE-Tribe Eragrosteae. Counts of $2 \mathrm{n}=60$ for Eragrostis diffusa. (fig. 4) and E. plumbea are the first for these taxa. Two counts of $2 n=16$ (fig. 5) were made for Erioneuron avenaceum and one count of $2 n=16$ was made for $E$. nealleyi. Tateoka (1961) had reported $2 \mathrm{n}=32$ for the former and $2 n=16$ for the latter. A count of $2 n=$ ca. 40 was obtained for Lycurus phleoides (fig. 6). This was the same as reported for an Argentinan collection of the species (Avdulov, 1931) but Brown (1951) reported $2 n=28$ for U.S.A. plants. The writer has obtained a count (unpublished) of $2 n=40$ from a Texas collection. In this 
material multivalents and univalents were numerous at prophase and metaphase stages of PMC division I.

Counts of $2 \mathrm{n}=40$ were obtained for Muhlenbergia pubescens, $M$. rigens and M. rigida (fig. 7). One collection of $M$. rigida had $2 n=44$ and irregular meiosis. Previous counts of $2 \mathrm{n}=40$ had been made for $M$. rigens (Stebbins and Love, 1941) and for $M$. rigida (Gould, 1958).

Counts of $2 \mathrm{n}=24$ were obtained for Sporobo'us indicus and S. trichodes (fig. 9). Tateoka (1962), reported $2 \mathrm{n}=36$ for the former and there are no previous records for the latter. Considerable irregularity was observed in PMC divisions of S. indicus from near Cordoba, Veracruz. In telophase I of one division, 12 chromosomes had gone to one pole and 10 to the other, with two chromosomes lagging on the equatorial plate. About one-fourth of the pollen tetrads had cells with one or more micronuclei. The record of $2 \mathrm{n}=36$ for $S$. poiretii (fig. 8 ) was the same as reported for this species by Brown (1951) and Bowden and Senn (1962).

The chromosome count of $2 n=60$ for Aegopogon tenellus is the first record for this genus. The relatively high chromosome number, presumably hexaploid, is es. pecially interesting in view of the uncertain systematic and phylogenetic relationships of Aegopogon.

A total of 48 counts are reported for 10 species of Bouteloua. The record of $2 n=20$ for $B$. barbata (fig. 10) was the same as previously reported for this species (Gould, 1958). Records of $2 \mathrm{n}=40$ for B. breviseta and B. chasei (fig. 11) are the first for these taxa. The tetraploid count of $2 n=40$ also was obtained for a collection of B. chondrosioides. Records of $2 \mathrm{n}=14$ (Brown, 1950), $2 \mathrm{n}=20$ (Freter and Brown, 1955), and $2 \mathrm{n}=40$ (Gould, 1958) previously had been reported for this species.

Nine diploid $(2 \mathrm{n}=20), 8$ tetraploid, one hexaploid, and two aneuploid counts were obtained for collections referrable to B. filiformis (fig. 12-14). This species is closely interrelated with $B$, radicosa for which six $2 n=60$ counts are reported (fig. 20). Previous records of B. filiformis were $2 n=14$ (Brown, 1950), $2 n=20$. 21, 22, (Snyder and Harlan, 1953), and 2n=46 (Tateoka, 1962). Records of $2 \mathrm{n}=20$ for B. radicosa (Freter and Brown, 1955) may have been bașed on plants of B. filiformis.

Chromosome numbers of $2 n=20,2 n=4.0$ and $2 n=60$ were obtained for collections of $B$. gracilis (fig. 15-16). Avdulov (1931) reported $2 n=50$ for this species and Fults (1942) published 5 aneuploid counts. In a study of plants of southwestern U.S.A., Snyder and Harlan (1953) reported counts of $2 n=20,40$, 42, 60, and 84. The tetraploid collection Gould 9595, from near Toluca, showed a strong tendency towards multivalent formation during PMC division I, prophase and metaphase, with all chromosomes entering into quadrivalent associations in some cases (fig. 16).

Four of five records of $B$. hirsuta were aneuploid $(2 \mathrm{n}=24,28$, ca..46, and ca. 52) and one was tetraploid, $2 \mathrm{n}=40$ (fig. 17-19). Diploids have been reported 
for this species (Gould, 1958) but published records (Fults, 1942; Brown, 1950 and 1951; Gould, 1958) and unpublished counts of the writer indicate a predominance of aneuploids in this species complex.

Counts of $2 n=20$ and $2 n=40$ were obtained for B. simplex (fig. 21). The $2 n=20$ number has been reported for two Texas collections (Gould, 1960) and an Argentinan collection (Covas, 1945). Fults (1942) reported $2 n=28$ for this species. The single record of $B$. trifida was $2 n=20$. A count of $2 n=28$ has been reported by Brown (1950).

The count of $2 \mathrm{n}=60$ for Buchloe dactyloides (fig. 22) was the same as obtained by Avdulov (1931) and Nielsen (1939). Records for three species of Cathes. tecum apparently are the first for this genus. Counts of $2 n=20$ were obtained for $C$. annum and $C$. multifidum and $2 \mathrm{n}=60$ for $C$. erectum.

Counts of $2 \mathrm{n}=80$ were recorded for Chloris chloridea (fig. 23) and C. sub. mutica. Previous records for C. submutica were $2 n=80$ (Avdulov, 1931; Gould, 1960 ) and $2 n=$ ca. 65 (Krishnaswamy, 1940). Two $2 n=100$ counts for $C$. rufescens (fig. 24) are the same as reported by Tateoka (1962). This is the highest chromosome number recorded for the genus Chloris.

The record of $2 n=74$ for Hilaria belangeri was the first of this aneuploid number for the species. One count of $2 n=72$ has been reported for this taxon (Brown \& Cole, 1951). Counts of $2 n=72$ for $H$. cenchroides (fig. 26) were the same as reported by Tateoka (1962). Records of $2 n=72$ and $2 n=74$ are the first for $H$. ciliata. In PMC division I prophase of the aneuploid $2 n=74$ plant, one ring of 4. was always prominent, and at metaphase I one pair of chromosomes separated from the others in about half of the cells. The chromosomes of the extra pair, however, separated nomally and were incorporated in the daughter cells.

A count of $2 \mathrm{n}=80$ for Leptochloa dubia is the same as previously reported for Texas plants (Gould, 1960). Tetraploids $(2 n=40)$ also have been reported (Covas, 1949; Gould, 1960). Counts of $2 \mathrm{n}=40$ were obtained for Microchloa kunthii (fig. 27) and Opizia stolonifera (fig. 28). The record of Microchloa is the first for this monotypic genus. Tateoka (1962) has reported a count of $2 n=43$ for a plant of $O$. stolonifera from Chiapas, México.

Subfamily PANICOIDEAE - Tribe Paniceae - The count of $2 n=36$ for Brachiaria meziana (fig. 29) was the first for this species. Records for $2 n=70$ were obtained for Cenchrus brownii, C. echinatus (fig. 33), and C. myosuroides, and $2 \mathrm{n}=34$. for $C$. ciliare (Pennisetum ciliare (L.) Link fig. 30-31)). Avdulov (1931) reported $2=34$ for $C$. brownii and $C$. echinatus and $2 \mathrm{n}=70$ for $C$. myosu. roides. Nunez (1952) and Tateoka (1962) reported $2 n=68$ for C. echinatus and Brown $(1950,1951)$ reported $2 n=54$ for C. myosuroides. DeLisle (1963) reported $2 n=34$ for $C$. brownii and $2 n=68$ for $C$. echinatus. Many and varied chromosome numbers have been listed for the economically important $C$. ciliare. DeLisle (1963) has reviewed these counts which are listed as $2 \mathrm{n}=32,34,35,36,40,43,44,48,52$, and 54 . 
Digitaria badia from near Hidalgo and D. leucites (fig. 37) from Cuernavaca both had chromosome numbers of $2 \mathrm{n}=108$. These counts, the first for both species, are the highest yet reported in the genus. Records of $2 n=36,70$, and 72 were obtained for D. californica (Trichachne californica (Benth.) Chase (fig. 34-36)). Previous counts were $2 \mathrm{n}=18$ (Krishnaswamy, 1940, as Panicum californicum Benth.) and $2 \mathrm{n}=36$ (Brown, 1951 and Bowden and Senn, 1962, both as Trichachne californica (Benth.) Chase). The count of $2 \mathrm{n}=36$ for D. insularis was the same as reported (as Trichachne insularis (L.) Nees) by Brown (1951) and Tateoka (1962).

The count of $2 \mathrm{n}=36$ for Eriochloa aristata (fig. 38) was the first for this species and the record of $2 \mathrm{n}=34$ was the first for Ixophorus unisetus (fig. 39) and the genus Ixophorus. It is interesting to note that $2 n=34$ has been reported for many species of the closely related genus Cenchrus. This number presumably has been derived from the basic number $\mathrm{x}=9$, with loss or fusion of two chromosomes at the tetraploid level.

A count of $2 \mathrm{n}=70$ was obtained for Leptoloma cognatum. Previous records of $2 n=36$ and $2 n=72$ were reported by Brown (1951) and $n=18,35$, and 36 by Gould (1960). Diploid $(2 n=18)$ records were obtained for three species of Pa. nicum, $P$. bulbosum, $P$. hallii, and $P$. hirticaule (fig. 40). Previous counts for P. bulbosum were $2 \mathrm{n}=54$ (Brown, 1951), $2 \mathrm{n}=70$ (Krishnaswamy, 1940) and $2 \mathrm{n}=72$ (Brown, 1951). The diploid count for $P$. hallii was earlier reported by Gould (1958) and the record for $P$. hirticaule was the first for the species. A count of $2 n=36$ for $P$. joorii (fig. 41 ) also was the first for the species. Re-examination of voucher specimens for previous Panicum chromosome counts by the writer has brought to light a misidentification of the collection Could 7950 from Chihuahua. This is $P$. arizonicum and not $P$. fasciculatum Swartz var. reticulatum (Torr.) Beal as reported (Gould, 1958).

The first record for Paspalum mutabile was obtained from a collection made near Valles, S. L. P. This was a tetraploid with $2 n=40$.

The count of $2 \mathrm{n}=78$ for Pennisetum setosum is the second record for this species, Avdulov (1931) having reported $2 n=54$. In the present study, irregular PMC meiosis was noted in the plant from Guerrero from which the count was obtained. Figure 32 is an anaphase I with 35 chromosomes going to each pole from disjunction of the homologous chromosomes of metaphase bivalent associations. Also present in a different plane are 8 chromosomes interpreted as univalents being distributed to either pole at random. Three counts of $2 n=36$ for Rhynchelytrum roseum were the same as reported by de Wet (1954) and Tateoka (1962). Records of $2 n=36$ and $2 n=72$ were obtained for plants of Setaria geniculata. Previous records were $2 \mathrm{n}=36$ (Gould, 1960) and 2n=72 (Brown, 1948; Gould, 1960).

Tribe Andropogoneae.-A count of $2 \mathrm{n}=60$ was recorded for plants from Taxco tentatively identified as Andropogon hirtifolius (Fig. 44). This was the first record for the species. The count of $2 \mathrm{n}=40$ was recorded for Andropogon ischaemum L. 
var. ischaemum (Bothriochloa ischaemum (L.) Keng.). (Fig. 42). Numerous counts of $2 n=40$ have been reported for this species and variety but none from plants growing spontaneously in North America. Andropogon ischaemum var. songaricus Rupr., with $2 \mathrm{n}=50$ chromosomes, has become common as an introduction in pastures and on roadsides throughout much of Texas. The record of $2 n=120$ for a collection of $A$. reevesii (Fig. 43) from Zimapán, Hidalgo, was the same as reported in the original description of this species (Gould, 1957). The Zimapán collection provided a second known station for this apparently rare grass which was described from plants grown from seed collected near Saltillo, Coahuila. The count of $2 n=20$ for Elyonurus tripsacoides var. ciliaris was the first for this variety and the same as reported for the typical variety by Brown (1951). 


\section{REFERENCES CITED}

Avdulov, N. P. 1931 Karyo-systematische Untersuchungen der Familie Gramineen. Bull. Appl. Bot. Pl. Breed. Suppl. 44.

Beaman, J. H., D. C. O. de Jong, and W. P. Stcutamire. 1962. Chromosome studies in the alpine and subalpine floras of Mexicc and Guatemala. Amer. Jour. Bot. 49:41-50.

Bowden, W. M., and H. A. Senn. 1962. Chromosome numbers in 28 grass genera from South America. Canad. Jour. Bct. 40:1115-1124.

Brown, W. V. 1948. A cytological study in the Gramineae. Amer. Jour. Bot. 35:382-395.

-_--. 1950. A cytological study of some Texas Gramineae. Bull. Torr. Club 77:63-76.

. 1951. Chromosome numbers of some Texas grasses. Bull Torr. Club 78:292-299.

-., and G. E. Cole. 1951. A study of sterility in Hilaria belangeri (Steud.) Nash and Hilaria mutica (Buckl.) Benth. Amer. Jcur. Bot. 10:82:3-830.

Covas, G. 1945. Número de cromosomas de algunas gramineas Argentinas. Rev. Argent. Agron. 12:315-317.

----. 1949. Estudios cariológicos en antofitas III. Darwiniana 9:158.

DeLisle, D. G. 1963. Taxonomy and distribution of the genus Cenchrus Iowa State Jour. Sci. 37:259-351.

Freter, L. E., and W. V. Brown. 1955. A cytotaxoncmic study of Bouteloua curtipendula and B. uniflora. Bull. Torr. Bot. Club 82:121-130.

Fults, J. L. 1942. Somatic chromosome complements in Bouteloua. Amer. Jour. Bot. 29:45-55. Gould, F. W. 1953. A cytotaxonomic study in the genus Andropogon. Amer. Jour. Bot. 40:297-306.

-. 1956. Chromosome counts and cytotaxonomic notes on grasses of the tribe Andropogoneae. Amer. Jour. Bot. 43:395-404.

-_-_. 1957. New North American andropogons of sugenus Amphilophis and a key to those species occurring in the United States. Madroño 14:18-29.

---. 1958. Chromosome numbers in southwestern grasses. Amer. Jour. Bot. 45:757-767.

1960. Chromosome numbers in southwestern grasses. II. Amer. Jour. Bot. 47:873-877.

1963. Cytotaxonomy of Digitaria sanguinalis and D. adscendens Brittonia 15:241-244.

-, and Z. J. Kapadia. 1964. Biosystematic studies in the Bouteloua curtipendula complex.

II. Taxonomy. Brittonia 16:182-207.

Krishnaswamy, N. 1940. Untersuchung zur Cytologie und Systematik der Gramineen. Beih. Bot. Centralbl. 60, 1-56.

Love, R. M. 1947. In W. M. Meyers, Cytology and genetics of forage grasses. Bot. Rev. $13: 319-421$.

Nielsen, E. L. 1939. Grass studies III. Additional somatic chromosome complements. Amer. Jour. Bot. 26:366-371.

Núñez, Ovidio. 1962. Investigaciones cariosistemáticas en las Gramíneas Argentinas de las tribus "Paniceae". Rev. La Plata Univ. Nac. Fac. de Agron. 28:229-256.

Snyder, L. A., and J. R. Harlan. 1953. A cytological study of Bouteloua gracilis from western Texas and eastern New Mexico. Amer. Jour. Bot. 40:702-707.

Stebbins, G. L. 1950. Variation and evolution in plants. Columbia Univ. Press. New York.

-_, and B. Crampton. 1961. A suggested revision of the grass genera of temperate North America. In The natural classification of the Gramineae. Recent Advances in Botany 133-145.

- - , and R. M. Love. 1941. A cytclogical study of California forage grasses. Amer. Jour. Bot. 28:371-382.

Tateoka, T. 1961. A biosystematic study cf Tridens (Gramineae). Amer. Jour. Bot. 48:565-573. 19:97-103.

-.- 1962. A cytological study of some Mexican grasses. Bull. Torr. Bot. Club 89:77-81. de Wet, J. M. J. 1954. Chromosome numbers of a few South African grasses. Cytologia 
BOLETIN DE LA SOCIEDAD BOTANICA DE MEXICO, No. 29

TABLE 1. Chromosome counts of Mexican grasses

Genus

Collection

Species

$2 n=$

Number

Locality

Trisetum

\section{SUBFAMILY FESTUCOIDEAE}

Tribe Aveneae

deyeuxioides (Kunth) Kunth $28 \quad 9614$ Michoacán. Hidalgo.

evolutum (Fourn.) Hitchc.* $28 \quad 9260$ Veracruz. Jalapa.

\section{Piptochaetium}

Tribe Stipeqe

brevicalyx (Fourn.) Ricker* $22 \quad 9211 \quad$ México. San Juan del Río.

fimbriatum (Kunth) Hitchc.* $42 \quad 9661 \quad$ San Luis Potosí. San Luis Potosí

Stipa

emines Cav.*

44

9660 San Luis Potosí. San Luis Potosí

SUBFAMILY ERAGROSTOIDEAE

Tribe Eragrosteae

Eragrostis

diffusa Buckl.*

60

9604

México. Toluca

plumbea Scribn.*

60

9612

Michoacán. Hidalgo.

Erioneuron

avenaceum (Kunth) Tateoka* 16

nealley (Vasey) Tateoka

16

9564 Hidalgo. Ixmiquilpan.

10157 Hidalgo. Pachuca.

Lycurus

phlecides Kunth ca. 40

9307

Hidalgo. Ixmiquilpan.

\section{Muhlenbergia}

pubescens (Kunth) Hitchc. ${ }^{*} \quad 40$

rigida (Kunth) Kunth ca. 40

9663

ca. 44

R3412 $^{1}$ Durango. Durango.

10193 México. Cd. Satélite.

"

* ca. 44

9662

San Luis Potosí. San Luis Potosí.

\section{Sporobulus}

indicus (L.) R. Br.*

poiretii (Roem. \& Schult.) Hitchc.

trichodes Hitchc.*

\section{Aegopogon*}

9238

9599

Veracruz. Córdoba.

9627

México. Toluca.

24

Tribe Chlorideae

Jalisco. South of Jiquilpan.

tenellus (DC.) Trin.*

60

9258

Veracruz. Jalapa.

* First report for taxon or count differing from previous reports. 
Genus

Species
Collection

$2 n=$ Number Locality

\section{Bouteloua}

barbata Lag.

breviseta Vasey*

chasei Swallen*

chondrosioides (Kunt) Benth. 40 filiformis (Fourn.) Griffiths 20

20

20

20

20

20

20

20

20

22

40

40

40

40

40

40

40

*ca. 45

*

gracilis (Willd. ex Kunth) Lag. 20 ex Griffiths

20

20

40

40
10120 San Luis Potosí. South of Matehuala

R3276 Coahuila Castaños.

10121 San Luis Potosí. South of Matehuala.

10261 San Luis Potosí. 85 miles north of San Luis Potosí.

9284 Oaxaca. Oaxaca.

9308 Hidalgo. Ixmiquilpan.

9554 San Luis Potosí. Valles.

10124 San Luis Potosí. Ciudad del Maíz.

10129 San Luis Potosí. Ciudad del Maíz.

10148 Hidalgo. Zimapán.

10188 México. Cd. Satélite.

10222 Querétaro. Querétaro.

10237 Guanajuato. Irapuato.

10243a Guerrero. Silao.

10222a Querétaro. Querétaro.

7908 Durango. Durango.

9267 Puebla. Atlixco.

9283 Oaxaca. Oaxaca.

9552 Tamaulipas. Cd. Mante.

9634 Jalisco. Tamazula.

9578 Guerrero. Taxco.

10322 Morelos. Cuernavaca.

10252a Jalisco. Lagos de Moreno.

10366 Guerrero. Acapulco.

7913 Durango. Durango.

10216 México. San Juan del Río.

10225 Querétaro. Querétaro.

8896a Chihuahua. Cd. Juárez

9595 México. Toluca.

${ }^{1}$ Numbers starting with the prefix $R$ refer to collection of $\mathrm{Dr}$. John $\mathrm{R}$. Reeder. The chromosome counts for those collections also were made by Dr. Reeder. 


\begin{tabular}{|c|c|c|c|}
\hline $\begin{array}{l}\text { Genus } \\
\text { Species }\end{array}$ & $2 n=$ & $\begin{array}{l}\text { Collection } \\
\text { N!umber }\end{array}$ & Locality \\
\hline \multicolumn{4}{|l|}{ Bouteloua (continued) } \\
\hline " & 40 & 9659 & $\begin{array}{l}\text { San Luis Potosí. San Luis } \\
\text { Potosí. }\end{array}$ \\
\hline " & 40 & 10150 & Hidalgo. Pachuca. \\
\hline ", & 40 & 10186 & México. Cd. Satélite. \\
\hline " & 40 & 10255 & $\begin{array}{l}\text { San Luis Potosí. East of } \\
\text { Lagos de Moreno. }\end{array}$ \\
\hline & 60 & 9265 & Ver. Perote. \\
\hline hirsuta Lag.* & 24 & 9592 & México. Toluca. \\
\hline " & 28 & 10147 & Hidalgo. Zimapán. \\
\hline$" 1$ & 40 & 9655 & Jalisco. Lagos de Moreno. \\
\hline$" 1$ & ca. 46 & 10223 & Querétaro. Querétaro. \\
\hline & ca. 52 & 10257 & Jalisco. Lagos de Moreno. \\
\hline radicosa (Fourn.) Griffiths* & 60 & 9008 & Jalisco. Lagos de Moreno. \\
\hline$\prime \prime$ & 60 & 9011 & $\begin{array}{l}\text { Jalisco. San Juan de los } \\
\text { Lagos. }\end{array}$ \\
\hline " & 60 & 9015 & Jalisco. Lagos de Moreno. \\
\hline " & 60 & 9651 & Jalisco. Tepatitlán. \\
\hline$" \prime$ & 60 & 9656 & Jalisco. Lagos de Moreno. \\
\hline$" 1$ & 60 & 10248 & Guanajuato. León. \\
\hline simplex Lag. & 20 & 10112 & $\begin{array}{l}\text { Nuevo León. South of } \\
\text { Saltillo. }\end{array}$ \\
\hline " & 40 & 10151 & Hidalgo. Pachuca. \\
\hline trifida Thurb.* & 20 & 9666 & Nuevo León. China. \\
\hline \multicolumn{4}{|l|}{ Buchloe } \\
\hline $\begin{array}{l}\text { dactyloides (Nutt.) Engelm. } \\
\text { Cathestecum* }\end{array}$ & \multicolumn{2}{|c|}{ Cathestecum* } & Hidalgo. Pachuca. \\
\hline annum Swallen* & 20 & 9274 & $\begin{array}{l}\text { Oaxaca. Huajuapan de } \\
\text { León. }\end{array}$ \\
\hline$"$ & 20 & 9579 & Guerrero. Iguala. \\
\hline erectum Vasey* & 60 & 9648 & Jalisco. Santa Ana. \\
\hline multifidum Griffiths* & 20 & 9276 & $\begin{array}{l}\text { Oaxaca. Huajuapan de } \\
\text { León. }\end{array}$ \\
\hline " & 20 & 9590 & $\begin{array}{l}\text { Guerrero. Grutas de } \\
\text { Cacahuamilpa. }\end{array}$ \\
\hline \multicolumn{4}{|l|}{ Chloris } \\
\hline $\begin{array}{l}\text { chlorides (Presl.) Hitchc.* } \\
\text { rufescens Lag. }\end{array}$ & $\begin{array}{r}80 \\
100\end{array}$ & $\begin{array}{r}10411 \\
9303\end{array}$ & $\begin{array}{l}\text { San Luis Potosí. Valles. } \\
\text { Hidalgo. Ixmiquilpan. }\end{array}$ \\
\hline submutica Kunth & 80 & 9615 & Michocán. Hidalgo. \\
\hline \multicolumn{4}{|l|}{ Hilaria } \\
\hline belangeri (Steud.) Nash* & 74 & 9583 & Guerrero. Chilpancingo. \\
\hline
\end{tabular}




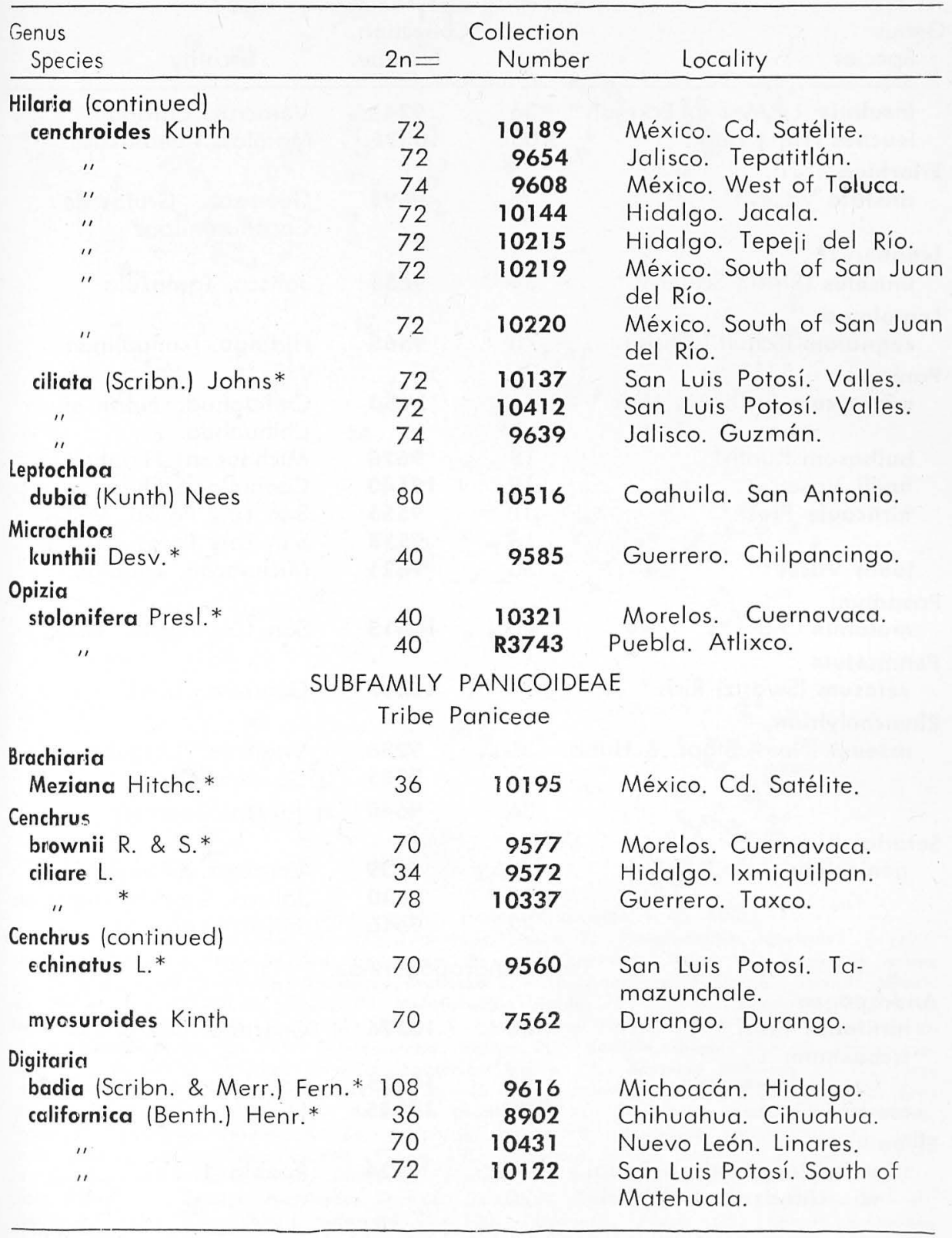


Genus

Collection

Species

$2 n=\quad$ Number

Locality

insularis (L.) Mez ex Eckman

36

leucites (Trin.) Henr.*

108

36

aristata Vasey*

Ixophorus*

unisetus (Presl.) Schlecht.* 34

Leptoloma

cognatum (Schult.) Chase $\quad 70$

Panicum

arizonicum Scribn. \& Merr.* 36

bulbosum Kunth*

18

hallii Vasey

hirticaule Presl.*

joorii" Vasey*

Paspalum

mutabile Chase*

Pennisetum

setosum (Swartz) Rich.* 78

Rhynchelytrum

roseum (Nees) Stapf. \& Hubb.

36

36

36

Setaria

geniculata (Lam.) Beauv.

72
9241

10388

9598

Guerrero. Grutas de Cacahuamilpa.

9635 Jalisco. Tamazula.

9565 Hidalgo. Ixmiquilpan.

7950 Chihuahua. North of Chihuahua.

9620 Michoacán. Hidalgo.

10540 Coahuila. Saltillo.

9555 San Luis Potosí. Valles.

9558 San Luis Potosí. Valles.

9621 Michoacán. Hidalgo.

10415 San Luis Potosí. Valles.

10337 Guerrero. Taxco.

9236 Veracruz. Córdoba.

9285 Oaxaca. Oaxaca.

9640 Jalisco. Guzmán.

9239 Veracruz. Córdoba.

9630 Jalisco. South of Jiquilpan.

9646 Jalisco. Guzmán.

Tribe Andropogoneae

Andropogon

hirtifolius Presl.*

ischaemum $L$.

var. ischaemum

reevesii Gould

Elyonurus

tripsacoides Humb. \& Bonpl.

var. ciliaris (Kunth) Hack.*
60

10326

40

120

10135

10145

9224
Guerrero. Taxco.

San Luis Potosí. Valles. Hidalgo. Zimapán.

20
Puebla. Puebla. 


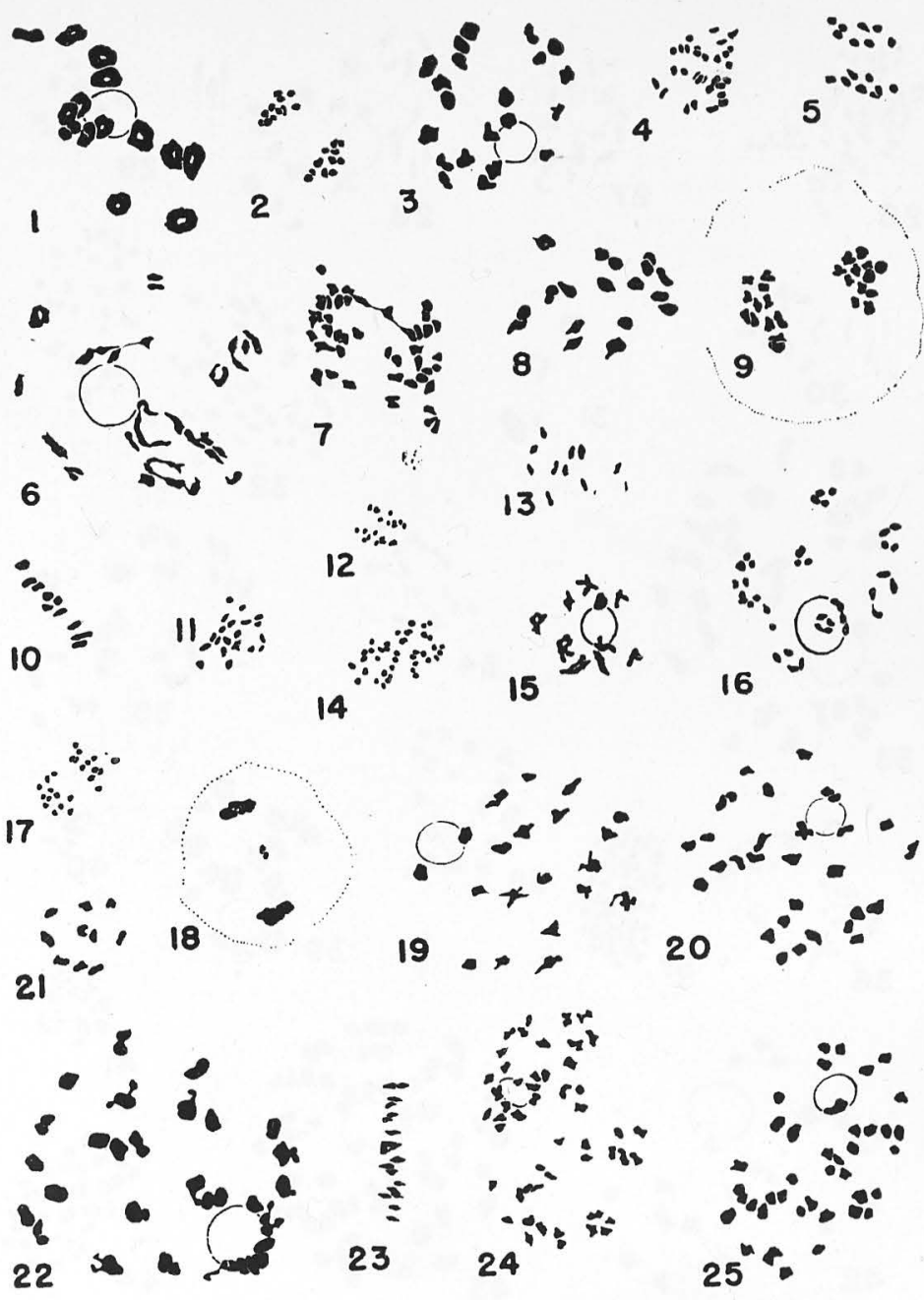

Figures 1-25. PMC meiosis, stages of division 1. ( $x$ 600).

Figure 1. Trisetum deyeuxoides $2 n=28$. Ciakinesis. Figure 2 . Piptochaetium brevicalyx $2 n=22$. Anaphase. Figure 3. Piptochaetium fimbriatum $2 n=42$. Diakinesis. Figure 4. Eragrostis difusa $2 n=60$. Metaphase. Figure 5. Erioneuron avenacea $2 n=16$. Anaphase. Figure 6 . Lycurus phleoides $2 n=c a$. 40. Diakinesis. Figure 7. Muhlenbergia rigida $2 n=c a .44$. Anaphase. Figure 8 . Sporobolus poirettii $2 n=36$. Metaphase. Figure 9. Sporobolus trichoides $2 n=24$. Telophase. Figure 10. Bouteloua simplex $2 n=20$. Prometaphase. Figure 22. Buchloe chasei $2 n=40$. Metaphase. Figure 12. Boufeloua filiformis $2 n=20$. Anaphase. Figure 13. Boufeloa filiformis $2 n=22$. Prometaphase. Figure 14. Boutelova filiformis $2 n=40$. Early anaphase. Figure 15. Bouteloua gracilis $2 n=20$. Diakinesis. Figure 16. Bouteloua gracilis $2 n=40$. Diakinesis; note the quadrivalents. Figure 17. Boutelova hirsuta $2 n=24$. Anaphase. Figure 18. Boufelova hirsuta $2 n=24$. Telo. phase, showing lagging chromosomes. Figure 19. Bouteloua hirsula $2 n=40$. Ciakinesis. Figure 20. Bouteloua radicosa $2 n=60$. Diakinesis. Figure 21. Bouteloua simplex $2 n=20$. Prometaphase. Figure 22. Buchloe dactyloides $2 n=60$. Diakinesis. Figure 23. Chloris chloridea $2 n=40$. Metaphase. Figure 24. Chloris rufescens $2 n=100$. Diakinesis. Figure 25 . Chloris submutica $2 n=80$. Diakinesis. 

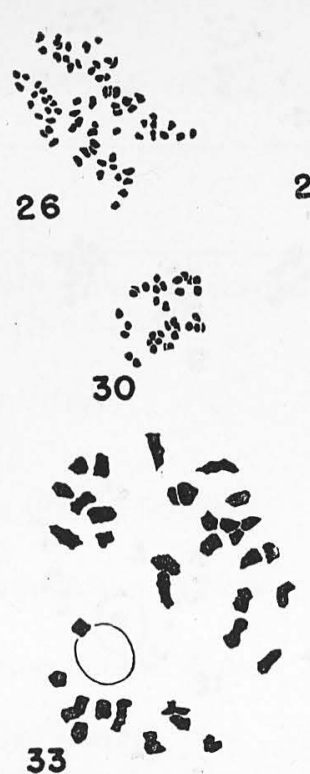

33

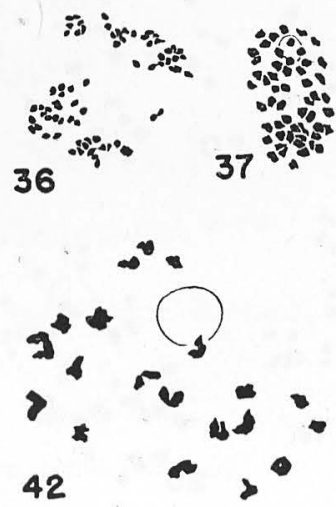

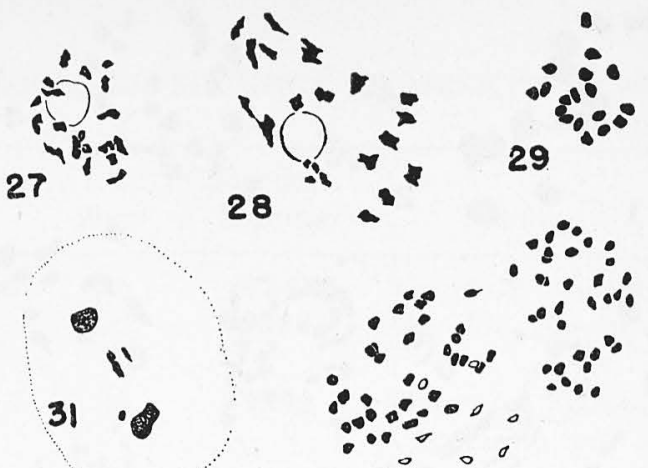

32

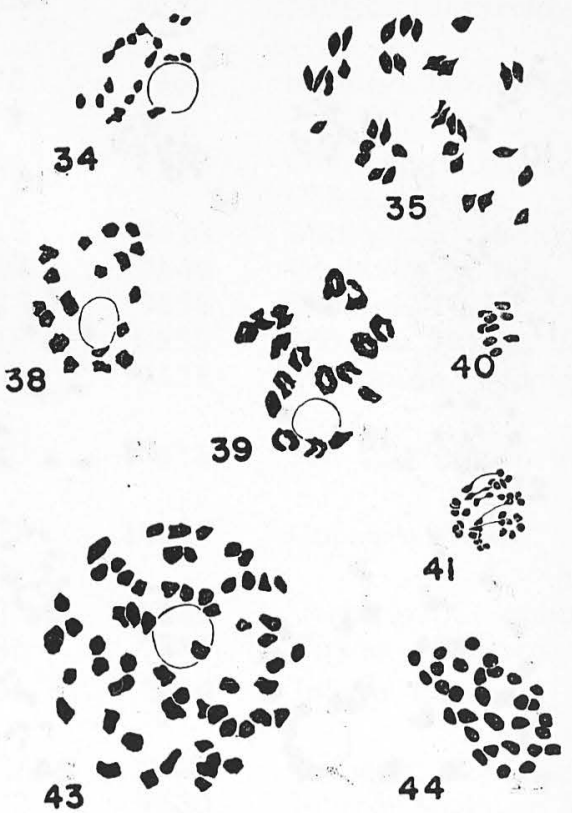

Figures 26-44. PMC meiosis, stages of division 1. ( $x$ 680)

Figure 26. Hilaria cenchroides $2 n=72$. Anaphase. Figure 27 . Microchloa kunthii $2 n=40$. Dia. kinesis. Figure 28. Opizia stolonifera $2 n=40$. Diakinesis. Figure 29. Brachiaria meziana $2 n=36$. Metaphase. Figure 30. Cenchrus ciliare $2 n=34$. Anaphase. Figure 31 . Cenchrus ciliare $2 n=34$. Telophase, note micronuclei. Figure 32. Pennisetum setosum $2 n=78$. Anaphase, with 35 chromo. somes going to each pole from disjunction of the homologous chromosomes of metaphase bi. valents and 8 chromosomes (white center) interpreted as univalents being distributed to the poles at random. The latter were in a different plane. Figure 3.3. Cenchrus echinatus $2 n=70$. Diakinesis. Figure 34. Digitaria californica $2 n=36$. Diakinesis. Figure 35. Digitaria californica $2 n=70$. Metaphase. Figure 36. Digitaria californica $2 n=72$. Anaphase. Figure 37. Digitaria leucites $2 n=108$. Diakinesis. Figure 38. Eriochloa aristata $2 n=36$. Diakinesis. Figure 39.. Ixophorus unisetus $2 n=34$. Diakinesis. Figure 40 . Panicum hirticaule $2 n=18$. Metaphase. Figure 41. Panicum joorii $2 n=36$. Anaphase. Figure 42. Andropogon ischaemum var. ischaemum $2 n=40$. Diakinesis. Figure 43. Andropogon reevesii $2 n=120$. Diakinesis. Figure 44 . Andropogon hirtifolius $2 n=60$. Metaphase. 